\title{
Moscow program of renovation of housing in the context of inter-party competition
}

\author{
Igor Andreev* \\ Moscow State University of Civil Engineering, Yaroslavskoe shosse, 26, Moscow, 129337, Russia
}

\begin{abstract}
The most prominent social-economic project started by the Moscow administration in 2017-2018 is the Housing Stock Renovation Program. The main political parties represented in the capital offered the citizens their interpretations of the initial variant of the program and the suggestions on its improvement. The author compares the potential of the political parties in the capital's and the federal authorities, shows the main aspects of the cross-party cooperation and competition regarding the legal documentation of the best, to their mind, variant of the program. The author also investigates the interconnection between the political parties and the civil society and, particularly, the specifics of the mass street protests, where the Muscovites expressed their ambiguous attitude to the renovation program. The author concludes that so-called «systemic» parties showed a high level of the cooperation, in the process of which they were able to develop mutually acceptable amendments to the initial variant of the renovation project and to document them in the relevant legislative acts. It is also important that the parties were able to widely inform the citizens on the essence of the project, to get acquainted with the public opinion regarding this issue through various «feedback» channels, and to weaken the state of anxiety experienced by a part of the society to some extent. The author supposes that during the implementation of such programs nationwide, it is reasonable to consider not only the mass experience of their normativelegal documentation but also the mechanisms of achieving the cross-party consensus demonstrated in Moscow as well as the interaction with the civil society on the solution of the relevant problems of social-economic development.
\end{abstract}

\section{Introduction}

The problem of the housing quality remains relevant from year to year. At the same time, it affects not only young people having no living space of their own but also the owners of time-worn flats in appalling conditions. In order to make the citizens better off, the government is developing various projects. One of them is the housing stock renovation program. It implies the demolition of the time-worn multicompartment buildings and rehousing of the residents to the newly erected buildings. The housing stock renovation programs implemented in Moscow have become the largest ones widely resonated throughout Russia.

\footnotetext{
* Corresponding author: andreev-i-v@yandex.ru
} 
In the 1990s, the administration of the Moscow Mayor Yuri Luzhkov initiated «The Program of Complex Renovation of the Five-Story Buildings' Districts of the First Period of Prefabricated Construction». During its implementation up to 2010, over 1700 buildings had been supposed to be settled apart and demolished; this task was generally solved.

In early 2017, the new capital's Mayor Sergey Sobyanin started a project of further renovation of the time-worn housing stock around threefold surpassing the previous program by its scale and implying demolition of the buildings previously considered as «not subjected to demolition». The initial stage of the second renovation program was accompanied by a keen public reaction in the mass media formulated a series of critical remarks regarding various aspects of the Moscow administration's project. They also made a reference to the issue on the degree of its applicability in the nationwide scale. There was also a series of street protest actions organized by the citizens of Moscow.

The main political parties represented in the capital (Communist Party of the Russian Federation (CPRF), «Yabloko», «Fair Russia» etc.) tried to exploit the situation. But their activity was not limited to the implementation of their «natural» function of articulation and aggregation of the public requests. The parties deliberately «ideologized» their evaluations of the renovation program, clarifying the connection of their evaluations with the contents of the parties' programs for the Moscow citizens. Thus they expected to expand their electorate and the political leverage during the election campaigns at the capital and federal levels.

Notably, the administration of both the Moscow Mayor and the faction of United Russia Party in the State Duma of the Russian Federation and the Moscow City Duma showed their readiness to consider the critical evaluations of the renovation program provided by their political opponents and to introduce necessary amendments to its original variant. Thus, they created an important precedent of finding a mutually acceptable solution of one of the acutest issues of social and economic development.

The subject matter of the report is the revealing of the main trends of interaction of the state government bodies, municipal government, political parties, public organizations and movements in the metropolitan area on finding a mutually acceptable solution of one of the acutest issues of social and economic development. The relevance of the research increases due to the fact that the ways of achieving the compromise on the housing stock renovation problem in Moscow may be of a particular interest for the solution of the same collisions in future, moreover not only at local but also at the federal level.

\section{Literature review}

Due to the fact that during the cross-party disputes the opponents often referred to the foreign experience of the housing stock renovation programs, the author has studied a series of publications on this subject. Particularly, the author has found an interesting material on the social, environmental and technological aspects of the housing stock renovation in the papers by P.A. Jensen, E. Maslesa, J. Brinkø Berg and C. Thuesen [1, 2], M. Monzón and B. López [3], J. Sedlák, P. Jelinek, Z. Stránská and K. Struhala [4], O. Pombo, B. Rivela and J. Neila [5], A. Kaklauskas, L. Tupenaite, L. Kanapeckiene, J. Naimaviciene [6]. The author also got acquainted with the estimates of the renovation program given by the leaders of political parties [7-11].

\section{Methods}

The author used the observation method when attending the political rallies dedicated to the discussion of the housing stock renovation program, and conducted a series of interviews 
with their participants. The author studied the documentary sources, such as regulatory acts governing the housing sector, minutes of meetings at the State Duma of the Russian Federation and the Moscow City Duma with the discussion of the legislative acts concerning the housing stock renovation problems in Moscow, as well as the documents of the political parties and public organizations.

\section{Results}

The System of Power Structures and Political Constellation in Moscow prior to the Implementation of the Housing Stock Renovation Program. We'll start with the political characteristic of the official bodies and the deputy corps of the municipal assemblies taking a determinative effect on the definition of the housing stock renovation program in Moscow. The key figure is undoubtedly the Mayor of the capital Sergey Sobyanin. In 2010, Sobyanin proposed by the then President of Russia Dmitry Medvedev was confirmed in this position in the Moscow City Duma, while in 2013 he was elected for this position by $51.37 \%$ of the popular vote. In those elections, he officially held himself as an independent, while they had been aware of his membership of the top echelon of United Russia party: since 2010 Sergey Sobyanin has been a member of the High Council Bureau of the «power party».

Notably, Sobyanin's election agenda contained three main directions of the cityplanning policy: preservation of the historic center, feasible reorganization of the industrial zones in the middle part of the city and sound development of the New Moscow territory. The housing stock renovation project was not mentioned in the agenda.

The Charter of Moscow endows mayor with sweeping powers. Particularly, mayor indirectly or through the executive authorities of the city solves the issues of social-economic development of Moscow and manages the city economy. Mayor forms the government of Moscow and decides upon its designation.

Also, Mayor has a great power of influence on the legislative activities of the City Duma being entitled to reject the laws adopted by it. Certainly, not to abuse the veto right, for the Mayor it is desirable to have the majority of the legislators on his side. Sobyanin never had troubles with it. In 2010-2014, his initiatives were always welcomed by the City Duma, 32 deputies of which (out of 35) represented United Russia party. And in 2014, Sobyanin gained the stable support of the new composition of the Moscow City Duma, 28 seats in which (out of 45, according to the new standard) were taken by the representatives of United Russia Party; the other 10 seats were taken by the independents creating the deputy association «My Moscow» supporting of United Russia Party in all the key issues. The communists holding themselves as the main segment of the left opposition gained 5 parliamentary seats; one deputy represents the Liberal-Democratic Party and another - the Motherland Party.

Alongside with it, a peculiarity of Moscow is a relatively high support of so-called «non-systemic» opposition by certain population groups. For the first time, the potential of this segment of the political spectrum manifested in 2011-2012, when the liberal activists were able to organize mass protest actions connected with the peculiarities of organization and the results of the presidential and parliamentary elections. The fast reaction of the federal legislative and executive authorities to these actions is remarkable: soon after the amendments were made to the legislative acts governing the political activities, which significantly facilitated the procedure of creation of new political parties and increased the degree of transparency and competitiveness of the election process.

In 2013, the «non-systemic» opposition achieved relative success in the competition with S. Sobyanin for the post of the mayor of Moscow: its representative A. Navalny unexpectedly took the second position with over $27 \%$ of the popular vote. Navalny based on the 
results of the three-year service of Sobyanin as the mayor, criticized such negative aspects of the city-planning policy of the Moscow administration as «territorial segregation» - increasing isolation of the citizens by the attribute of their property, dehumanization of the city environment, monopolization of the construction market by several large companies etc. In this aspect, by the way, the other participants of the election race were sympathetic to Navalny. As it will be further shown, the opponents of the Sobyanin's housing stock renovation program interpreted it as a particular manifestation of these unfavorable development trends in the city-planning sphere.

The relative success of the «non-systemic» opposition at the mayor elections, however, was not accompanied with the consolidation of its positions in the City Duma, as we already mentioned above. But there was a significant shift in the elections for the Councils of Deputies of the Moscow Municipalities in September 2017: in 7 districts of the city (out of 125) the citizens elected no candidate from the power party, in 25 districts United Russia Party obtained the minority of mandates, in 5 districts United Russia Party and the opposition obtained equal number of mandates. The Yabloko Party confirmed the status of the leading party structure of the «non-systemic» opposition in Moscow with 176 seats out of 1502 (by 152 more in relation to the previous elections). One should also note the failure of the center-left parties relating to the «systemic» opposition - the Communist Party of the Russian Federation only obtained 44 seats (by 159 less in relation to the previous elections), while Fair Russia Party - 10 seats (by 124 less).

As for the implementation of the housing stock renovation program in Moscow the State Duma of Russia needed to make amendments to the applicable nationwide legislation, one should also characterize the political constellation in this body. The fraction of United Russia Party had in the lower chamber of parliament the constitutional majority of 340 seats (out of 450). The communists seated 43 deputies to the Duma, the Liberal-Democratic Party -40 , and Fair Russia Party - 23. The representatives of the Yabloko Party, the same as of the other structures deemed to be related to the «non-systemic» opposition, were not elected to the Duma of this convocation.

Thus, both at the federal and at the Moscow level of the representative authority, the political support of the housing stock renovation program in the capital initiated by Sergey Sobyanin was ensured. However, it did not relieve the administration of the Moscow Mayor from the necessity of correcting the exposure draft of the program responding to the critics of the political opponents, as it will be shown below.

Housing Stock Renovation Program in Moscow: Original Variant. The launch of the program on the demolition of the five-story buildings in Moscow was declared in February 2017, when the capital governor put forward the draft at the meeting of the Council of the Moscow Municipalities. One announced the liquidation of 5144 old multicompartment buildings with the total area of about 25 million square meters, which amounted to about $10 \%$ of the entire housing stock in Moscow. Underlining the grandness of the program, S. Sobyanin stated that it surpassed the program of preparation for the Sochi Olympics, Vladivostok OPEC, and the FIFA World Cup by its scale. Over one and a half million people living in the buildings subject to demolition obtained the right of acquiring flats. At the same time, it was stipulated that the new flats would be provided to the citizens of Moscow in their native or neighboring districts. If required, the people could choose the location of the new residence on their own, but upon submitting a written consent.

In the days to come, the city governor's idea obtained positive feedback from the majority of the City Duma deputies and the members of the Moscow Public Chamber. On February 21, 2017, at the meeting with S. Sobyanin, Vladimir Putin authorized the Mayor to continue rehousing the residents of the five-story buildings. The Mayor asked the President's assistance in the change of a series of the public and city-planning legal standards hindering the prompt implementation of the program. 
The Reaction of the Yabloko Party. The fastest and the most different was the reaction to the renovation program from the Yabloko Party, not only criticizing it but suggesting an alternative project and organizing mass protest actions. At the same time, the party underlined it had always stood for the renovation of the housing stock of Moscow the same as of the other Russian cities. The party stands against not the renovation of the housing stock in general but only this variant of renovation which, in their view, could have had negative economic, environmental and socio-psychological consequences.

Naturally, the party activists could not ignore the point of whose interests the renovation program represents. To their mind, it would be too optimistic to hope the program is really able to help the Moscow citizens move to better housing. But a significant profit from the program implementation will be certainly gained by the real estate developers operating on a monopolistic basis and the officials supervising the construction sphere of the capital. Besides, the promises to improve the housing conditions of one and a half million people are by themselves a good PR campaign on the eve of the elections for the president of Russia and the mayor of Moscow 2018.

The alternative proposal of the Yabloko Party may be divided into two units conventionally marked as «A Plan» and «B Plan».

«A Plan» is an optimal model of the housing stock renovation, which could be implemented in the case of the city authorities' refusal from their renovation program. First of all, this approach suggests considering the housing stock of Moscow and the country in general as «a part of the national wealth», where only a small part of time-worn housing is replaced by the new one. At the same time, the efforts should be directed to the modernization of the housing also with the consideration of the European experience. Second, they suggest significantly democratizing the decision-making process by entitling the residents themselves to decide upon the ways they are going to use to renovate their housing. According to the head of the Moscow organization of the Yabloko Party S. Mitrokhin, this plan could «have solved the housing problem quietly, avoiding working by spurts and compulsory, forced evictions» [7].

The «B Plan» more suitable for the modern realia implies, according to S. Mitrokhin, conducting the actions with the purpose of forcing the authorities if not to fully refuse from the implementation of their renovation program, then at the very least to exclude «the most irresponsible and dangerous provisions» from it. Particularly, S. Mitrokhin suggests including into the demolition program predominantly the failing buildings and municipal residential facilities «where people live in horrible conditions». The rest of the housing is to be demolished only in case of the consent of more than a half of the residents. And as the legally documented right for rehousing within the «native» district is often not implemented in practice, then the people should be precisely informed of the districts they are going to be rehoused to; at the same time, in these (new) districts it is suggested holding the public hearings and not starting the construction works in the places, which the locals are adamantly opposed to. The party also promises to render the methodical and legal assistance to the citizens facing various problems during the renovation program imposed by the authorities, including the assistance in the self-organization of the homeowners $[8,9]$.

For the purpose of practical implementation of their proposals, in May 2017 Yabloko initiated the creation of the Moscow Savior Committee. The organizational meeting was attended by the activists from 44 districts of Moscow. S. Mitrokhin was elected as the chairman of the committee. As it was declared, the task of the Committee was the opposition to the «destructive» policy of Mayor S. Sobyanin, the development of the alternative city-planning policy, organization of mutual assistance among the Moscow citizens and their initiative groups at the self-defense from the harmful city-planning projects and plans [10]. 
The Opinion of the Communist Party of the Russian Federation. The communists having immediately after introduced the idea of continuing the housing stock renovation process underlined they were the opponents both of its complete negation and of mindless approval of its original version. (By the way, the leader of the communists' fraction in the Moscow City Duma A. Klychkov reminded that particularly the communists' fraction suggested stipulating in the city budget 2017 the allocation of 30 billion for rehousing the residents of the time-worn five-story buildings, but the representatives of United Russia Party not yet informed of the future initiative of the governor, provided no consent for it). At the same time, the communists stood for the implementation of the renovation idea in a wider context. First, they suggested, minding the huge scale of the program, significantly revising the General Development Plan of Moscow adopted in 2010 or even adopting a new General Plan. To their mind, only in this case the systemic infrastructural (transport, engineering, social-cultural, environmental etc.) provision of the newly built housing is possible. Second, they paid attention to the threat of the increase in the «anti-Moscow'» mindsets among the people living in the regions with the housing stock of worse quality in relation to the Moscow citizens, and not having the capital's financial opportunities for implementation of the housing renovation programs. The communists stood for the preparation of the AllRussian housing stock renovation program financed by the state budget.

Alongside with it, realizing that these approaches cannot be implemented in the modern conditions, the communists focused their efforts on the correction of the draft program suggested by the Mayor. Particularly, they suggested guaranteeing the provision of the rehoused citizens with not only «equally-priced'» but with «equally-conditioned'» housing, as well as non-living premises; ensuring the provision of the rehoused citizens on the waiting list with the $18 \mathrm{~m}^{2}$ residential area per person stipulated by the former legislation. They also suggested legally documenting the inventory of firm sanitary-engineering standards at the construction of the new flats, which could really ensure their 70-100-year preservation. The communists were adamantly opposed to the renovation law of «simplified» procedure with compulsory eviction of the citizens declined the proposed rehousing variants stipulated in the initial draft law.

Some high-ranking communists compared to the representatives of the Yabloko Party elite presumed the possibility of good intentions guiding the authors of the renovation project. So, the deputy of the Moscow City Duma N. Zubrilin presumed they aspired to «revive the construction market, and to realize the unsold flats...» and admitted «there is nothing bad in it». Alongside with it, he underlined the insufficient elaboration of the renovation project, lack of proper state and public control over its implementation might lead to the fact that «the most powerful oligarchical structures» ruling in the construction sphere will not just gain the revenues, but gain «the surplus profit unearned and stolen» (the part of which will be certainly shared with the officials that were able to ensure the adoption by the executive authorities of the decisions «necessary» for the construction business) [11].

The communists proposed a point on the impossibility of socially-oriented correction of the renovation draft law without the active mass support «from below». «We undoubtedly stand for the support... of the social protest, where every person protects his or her property and chooses the adequate city development, - A. Klychkov declared. - We go a parallel way for the achievement of the common goal, for the protection of the Moscow citizen's rights, brushing off both the ideas of the Mayor and the real estate developer. And it will have a result». The politician concluded the party was facing the task of unifying the «street protest and the parliament activities» [12].

Fair Russia Party and the Liberal-Democratic Party supported the idea of updating the housing stock of Moscow, at the same time putting forward a number of proposals to improve the initial renovation project. 


\section{Consideration of the Draft Laws on the House Stock Renovation in the State Duma and the Moscow City Duma.}

On March 10, 2017, several deputies of United Russia Party introduced draft law No.120505-7 to the State Duma, which implied the correction of some norms of the general federal legislation «regarding the determination of the peculiarities of the housing stock renovation» in Moscow; people called it the «Renovation Law». The draft law, as noted by many deputies and journalists, had many significant drawbacks. Nevertheless, on April 20, the State Duma approved the basic concept of the draft law at the first reading, at the same time, if the factions of United Russia Party, the Communist Party of the Russian Federation and the Liberal Democratic Party of Russia stood «for» it, then the majority of the faction of Fair Russia Party abstained.

The work of the party factions of the State Duma on the draft law improvement was focused on the elaboration of the following issues: the rehousing «equivalency» and «equal value» criteria; the procedure of detection of the residents' consents to move to the new housing; the guarantees of provision of the new housing in the same district; the guarantees of the proper quality of the new housing and its infrastructure.

Simultaneously, the draft was being elaborated in the Moscow City Duma. On May 17, its deputies adopted the law safeguarding the interests of the housing residents involved in the renovation project. The communists and representatives of the other opposition parties voted in favor of this law.

The parliamentary activities were accompanied by the street protests of both the advocates and opponents of the renovation project. Especially large opponents' rally took place on May 14, at the Sakharov Avenue (according to the organizers of the protest, it involved 20,000 people, while according to the police, their number was 5,000). Notably, among the organizers and speechmakers of the protests, the prevailing were the representatives of the parties and organizations of the «non-systemic» opposition - Yabloko, Parnas, «Open Russia», Party of $5^{\text {th }}$ December etc. The opposition political activists estimated the impact of the protests on the draft law improvement procedure differently. So, a communist A.E. Klychkov stated that it is particularly the scales of the $14^{\text {th }}$ May protest that greatly affected the pro-government majority of the Moscow Duma and forced it to adopt all the amendments proposed by the communists' faction. On the contrary, the chairperson of the regional council of Fair Russia Party A.V. Tumanov supposed that at the rallies the people just «venting», while the results have no impact on what is happening [13].

The author of this report presented at a series of rallies and spoke with some participants. He has got an impression that often the motives of a protest are the phenomena of social-psychological nature that cannot be eliminated by any legal guarantees: the reluctance to leave a habitual social, infrastructural and ecological environment; the fear of the «stressful» rehousing procedure and shift to the unknown and, probably, uncomfortable surroundings etc.

Remarkably, if the opposition factions of the State Duma prepared their amendments to the draft law as early as by mid-May, then the faction of United Russia Party preferred not to hasten with the reply until the public opinion regarding this matter is totally clarified. One of the ways of achieving this goal was the voting on the renovation project held through the web-portal of the Moscow administration «Active Citizen» and in the districts' multifunctional centers of state services from May 15 to June 15 . Undoubtedly, as the results of the surveying had been evident beforehand, this measure was also planned as a means of affecting the minds of unsympathetic and undecided residents of the houses subject to eviction. The activity of the Muscovites was high: $71 \%$ voting from 4359 houses included in the preliminary list of the program. At the same time, the residents of 4073 houses voted in favor of moving to the new housing, while the residents of 466 houses stood against it. $84 \%$ of the citizens refused to move, appeared to be the residents of brick 
five-story buildings [14]. Another method of revealing of the public opinion was the conduction of the public hearings, the most remarkable of which took place on June 6 in the State Duma. Several hundreds of residents of the houses included in the renovation program had been invited to the hearings; their opinions of the project were heard from the Vice Prime Minister of the Russian government D. Kozak, the Minister of Construction and Housing-and-Utility Complex of Russia M. Men', Chairperson of the State Duma V. Volodin, and the Mayor of Moscow S. Sobyanin. The unsympathetic citizens were carrying their point of inclusion of the additional provision to the renovation program to the draft law, which is the housing technical condition.

When estimating the situation regarding the discussion of the renovation draft law as of early June, the Chairperson of the Duma Transportation and Construction Committee E. Moskvichev noted that the Committee had received 144 amendments from the Government of Russia and from the deputies, $90 \%$ of which were recommended by the Committee to the adoption at the second hearing. A series of valuable suggestions were selected by the Parliamentary Commission on Submission of the Citizens' Proposals spearheaded by the ViceChairperson of the State Duma P. Tolstoy.

V. Volodin stated that the party factions of the State Duma avoided the politicization of the problem of the housing stock renovation in Moscow and formulated rather compatible proposals on the improvement of the initial variant of the draft law. "We have neither right nor left ones, - he underlined. - We just have problems to solve» [15]. The draft law «has been jointly elaborated by all the factions of the State Duma», - P. Tolstoy also shared this opinion [16]. V. Volodin noted that the specifics of the amendments to the draft law are rather seen at comparing the proposals of the deputies' corpus and the government. The amendments of the deputies better safeguard the rights of the flat owners and ensure efficient procedures of revealing of the public opinion, while the governmental ones specificate the categories of the houses included in the renovation program and the rehousing procedure [17].

Meanwhile, S. Sobyanin noted an unusually democratic nature of the interaction between the state and municipal authorities with the population. During the implementation of the previous housing stock renovation program, he reminded that «nobody gave ear to the opinion of the citizens, still less left them the right of exiting the program» [15].

P. Tolstoy underlined that the joint work of all the parliamentary factions changed the draft law «drastically» having significantly expanded the guarantees of the citizens' rights [18]. And one may agree with this estimate because the renovation law adopted in early June 2017 contained the following important points, which had been absent in its initial variant.

- The list of the houses subject to eviction may only include the buildings constructed in 1957-1968 and not exceeding 9 stories.

- New flats provided to the rehoused citizens should be of the same value as the old ones.

- At least $2 / 3$ of the residents of the houses subject to eviction should express their consent to rehouse at the residents' meetings.

- The new buildings will be provided with modern utilities, transportation, and social infrastructure.

- The failing buildings are included in the renovation program regardless of the opinion of the residents.

It is also notable that the State Duma has formed a cross-faction committee aimed at control over the legitimacy of the Moscow administration activities on the renovation program implementation. 
At the same time, one should note that the parties of the «non-systemic» opposition also rejected the final version of the Renovation Law. Probably, this is caused by their position to remain opposed to the «power» in any issues.

\section{Discussion}

The author made a series of remarks regarding this subject matter in the course of scientific conferences and several «round tables» held in the Moscow State Construction University in 2017-2018. The colleagues recommended the author to take an in-depth research of the social group of the uncompromising opponents of the renovation, of their extent of involvedness to the previous protests, as well as the forms of interaction with the parties and organizations of the «non-systemic» opposition.

\section{Conclusions}

A special significance of the subject matter is caused not only by the unique role of Moscow and the social-political situation in the capital in the life of Russia. In the nearest future, many cities of the country will experience the housing stock renovation programs that will affect dozens of millions of the citizens. That's why a rather acute task is becoming the task of ensuring a smooth social context of the renovation program.

The second stage of renovation of the housing stock in Moscow, started in 2017, is characterized not only by its scale, but also by a higher level of public relations of the Moscow administration. From the very beginning, the Moscow government has demonstrated that it has no intention to impose on society the original version of the renovation of housing, using its «administrative resource» and the dominant position of United Russia party in the City Duma and the State Duma of Russia. On the contrary, the Moscow government was able to provide detailed information to Muscovites about the socially oriented design of the renovation project and take into account their views on the project.

The level of inter-party cooperation turned out to be qualitatively different too. The proximity of the approaches of the parties «United Russia», the Communist party, the LDPR, «Fair Russia» was due primarily, in our opinion, a very high degree of support for the General idea of the renovation project by the population of Moscow. Particularly interesting is the experience of the cross-faction committees on the preparation of the legislative base of the house stock renovation and control over the legitimacy of the renovation program implementation. The experience of the political parties in the revealing of the public opinion and proposals of the citizens, conducting discussions, the definition of the most appropriate forms of mass support by the population of the party's position regarding this spectrum of problems is also rather relevant.

The author believes that the experience of interaction between the government of Moscow, political parties and the population should be considered as one of the important guidelines in the development and implementation of housing renovation programs in other cities of Russia.

The negative position of the Yabloko Party, which it held throughout the period of preparation of the draft law on housing renovation, is, in our opinion, primarily due to political reasons. Undoubtedly the Yabloko Party considered its «irreconcilable» opposition to the proposed by «party of power» renovation project as a significant direction of its election campaign, which brought it, as noted above, success in the municipal elections in September 2017. At the same time, we believe that a number of arguments against the renovation project put forward by the Yabloko Party are not opportunistic and should be taken into account in the future. 
An interesting problem subject to further study is the motivation of the population groups standing against the renovation program. But even now it is clear that the behavior of some of such citizens is defined by the above-mentioned motives of a psychological nature; another part is reluctant to leave their old rather solid and comfortable housings; while the third ones feel the need of remaining loyal to the parties of the «non-systemic» opposition in any situation.

\section{References}

1. P.A. Jensen, E. Maslesa, J. Brinkø Berg, C. Thuesen, 10 questions concerning sustainable building renovation, Building a. Environment, 143, 130-137 (2018).

2. P.A. Jensen, E. Maslesa, Value based building renovation - a tool for decision-making and evaluation, Building a. Environment, 92, 1-9 (2015).

3. M. Monzón, B. López, Buildings performance indicates to prioritise multy-family housing renovations, Sustainable Cities a. Society, 38, 109-122 (2018).

4. J. Sedlák, P. Jelinek, Z. Stránská, K. Struhala, Environmental aspects of renovations case studies, Energia Procedia, 78, 2391-2396 (2015).

5. O. Pombo, B. Rivela, J. Neila, The challenge of sustainable building renovation: assessment of current criteria and future outlook, Journal of Cleaner Production, 123, 88100 (2016).

6. A. Kaklauskas, L. Tupenaite, L. Kanapeckiene, J. Naimaviciene, Knowledge-based model for standard housing renovation, Procedia Eng., 57, 497-503 (2013).

7. Rekonstruktsiya kak al'ternativa «renovatsii» (Reconstruction as an alternative to «renovation») URL: https://www.yabloko.ru/publikatsii/2017/06/15

8. Moskovskie pyatietatazhki (Moscow five-storey buildings) URL: https://www.yabloko.ru/node/36315

9. Snos pyatietatazhek protivorechit Konstitutsii (Demolition of five-storey buildings is contrary to the Constitution) URL: https://www.yabloko.ru/regnews/Moscow/2017/04/07

10. Zhiteli 44 rayonov stolitsy sozdali Komitet spaseniya Moskvy (Residents of 44 districts of the capital have created a rescue Committee in Moscow) URL: https://www.yabloko.ru/regnews/Moscow/2017/05/18

11. D'jachenko A. Podvodnye kamni renovatsii (Pitfalls of renovation) // Pravda. 2018. May 12-15.

12. Soedinit' ulichnyj protest i parlamentskuju dejatel'nost' (To join the street protest and parliamentary activities) // Pravda. 2018. May 16-17.

13. Moskva: RO SR provelo press-konferentsiyu «Moskva-2017: bez revolyutsii, no s renovatsiej?» (The regional branch of «Fair Russia» held a press conference «Moscow2017: without revolution, but with renovation?») URL: https://www.spravedlivo.ru/8262610

14. Shevrygin M. Moskovskiy opyt renovatsii zhilja mogut perenesti na vsju stranu (Moscow experience of renovating housing can move all over the country) // Parlamentskaya gazeta (Parliamentary newspaper). 2017. 23-29.06.

15. Melnik G. Renovatsiya s popravkoj (Renovation with a correction) // Parlamentskaya gazeta (Parliamentary newspaper). 2017. 9-15.06. 
16. Dialog s zhitelyami khrushhovok prodolzhitsya (Dialogue with residents of the fivestory buildings will continue) // Parlamentskaya gazeta (Parliamentary newspaper). 2017. 9-15.06.

17. Redichkina X. Zakonoproekt o renovatsii popravyat $\mathrm{v}$ hode parlamentskih slushanij (The bill on the renovation will be corrected in the course of parliamentary hearings) // Parlamentskaya gazeta (Parliamentary newspaper). 2017. 2-8.06.

18. Volkova O., Shul'ga O. Zakon o moskovskoj renovatsii usovershenstvovali (The law on Moscow renovation improved) // Parlamentskaya gazeta (Parliamentary newspaper). 2017. 16-22.06. 